http://artnodes.uoc.edu

ARTICLE

NEW MEDIA, ART-SCIENCE AND CONTEMPORARY ART: TOWARDS A HYBRID DISCOURSE?

\title{
The Artist in the Laboratory: Co-operating (T)reasonably
}

\author{
Jane Prophet \\ Professor of Art and Interdisciplinary Computing \\ Goldsmiths College University of London
}

Submission date: June, 2011

Accepted date: September, 2011

Published in: November, 2011

\begin{abstract}
The title uses collaborator in its less popular sense: "To cooperate treasonably, as with an enemy occupation force in one's country". The notion of the collaborator is immediately problematized and I will briefly introduce ways in which art-science collaborations can be seen as treasonable co-operations, by arbiters of taste from both the arts and the sciences. In brief, I will suggest that before rapprochement can take place, we need a more nuanced understanding of the gaps between art made with new media, mainstream contemporary art and sciart. My paper, drawing on my own experiences as an artist who has exhibited in all three circuits (with greater and lesser success) will seek to map this no man's land, this gap. My intention is to explore the nature of the gap between the discourses of mainstream contemporary art, new media, and sciart in order that we might better traverse it.
\end{abstract}

\section{Keywords}

new media art, mainstream contemporary art

\section{El artista en el laboratorio: una cooperación razonablemente traicionera}

\section{Resumen}

El título de este artículo utiliza la noción de colaborador en el sentido de colaboracionista, es decir, de «cooperar a traición, como por ejemplo con la fuerza de ocupación enemiga en el propio país». La idea del colaborador entra en conflicto de inmediato, e introduciré brevemente modos en los que las colaboraciones entre arte y ciencia pueden considerarse cooperaciones a traición, tanto para los árbitros del gusto de las artes como para los de las ciencias. En resumen, sugeriré que antes de que se pueda producir un acercamiento, necesitamos una 


\section{artnodes}

http://artnodes.uoc.edu

The Artist in the Laboratory: Co-operating (T)reasonably

comprensión más matizada de las brechas que se establecen entre el arte de los nuevos medios, el arte contemporáneo mayoritario y el arte-ciencia o sciart. El artículo, basado en mis propias experiencias como artista que ha expuesto (con mayor o menor éxito) en los tres circuitos, procurará delimitar esta tierra de nadie, esta brecha. Mi intención es explorar la naturaleza de esta brecha entre los discursos del arte contemporáneo mayoritario, los nuevos medios y el arte-ciencia para poder atravesarla mejor.

\section{Palabras clave}

arte de los nuevos medios, arte contemporáneo mayoritario

\section{Introduction}

I write from my experience as a practicing artist working with new media and who often collaborates with scientists. Ten years ago I largely stopped exhibiting my work on the new media art (NMA) circuit, instead exhibiting in more mainstream contemporary art (MCA) venues. My decision came from a feeling that, while the associated technologies, theories and debates of NMA were (and remain) important to my practice, their primary impact was on my way of thinking. Explicitly foregrounding these technical issues in each artwork is of less interest to me. In the late 1990s I found the debate on the NMA circuit to be highly stimulating, but somewhat limited and technologically determined. There were other aspects of my ideas and artworks that I wanted critiqued and discussed and I found them sidelined in debates. For me, as Nicholas Bourriaud (2010) said, technology is a part of contemporary art's production system, but only a part. In light of the trajectory of my practice, and the fact that I have not been exhibiting on the NMA circuit for many years, I will focus my comments on so-called sciart, rather than NMA, though new media remains central to my ideas, with computing and digital technologies and processes remaining important to my art production. The gap that I explore is a no man's land that lies between three differing territories: MCA, NMA and the (even less defined) sciart.

\section{Occupied territory}

Sciart collaborations (and the art made as a result of them) are often seen as treason by experts from both the arts and the sciences. Some scientists, like the British developmental biologist Lewis Wolpert, see such collaborations as inherently one-sided with the artists mere parasites feeding off scientists, "[a]|though science has had a strong influence on certain artists [...] art has contributed virtually nothing to science" (Wolpert, 2002). A close reading of the criteria for funding science/art collaborations, implies a subjugation of the art in an attempt to use such projects to fulfill the 'public engagement with science' remits of major funding bodies like The Wellcome Trust. In this example there is often an unequal power relationship, similar to that of a collaborator who works with an enemy-occupier. The artist 'collaborator' in this scenario has less power, the scientist and funders have the upper hand. By contrast, in CELL (Prophet et al., 2006) I was part of an interdisciplinary collaboration that investigated innovative theories of stem cell behaviour. We were funded by Wellcome for $R \& D$ and not being tied to the specific 'outcomes' that form part of Wellcome's larger production grants freed us from many of these constraints. Each of the individuals in CELL operated within a different research environment: Neil Theise's (Beth Israel) medical laboratory; Mark d'Inverno's (Goldsmiths College) and Rob Saunders' (University of Sydney) respective mathematical and computer science labs; and my artist's studio provided different and specific contexts for the work and came with particular embedded methodologies and ideologies that influenced the way our research, and resulting artworks and papers, developed.

Although there was a great deal of altruism between us, at times we were in opposition to one another (d'Inverno et al., 2005) and we often felt as though our partnership was frowned upon by peers from our respective disciplines. As the months went by, and one or another of us delayed the production of an output in our own field in order to further the work of one of our partners from another discipline, we were challenged by peers about our collaboration. I denied art production in order to make simulations for science; Theise focused on an arts text rather than another paper for the journal Nature. Our work together was situated in a no man's land of conflicting cultures, ranging from the hypothesis-driven ethos of the medical research lab, to the reflexive practice of the art studio, to the empirically driven environment of mathematics. I say no man's land because this term is traditionally used to describe a place that is unoccupied or is under dispute between parties, one that is left unoccupied due to fear or uncertainty. The negative connotations of collaboration, the sense of having infiltrated an occupied territory, were strong in the CELL collaboration, despite the warmth that we felt for one another. We openly debated whether co-authoring texts and collaborative artifact production were potentially damaging to the scientists' reputations, especially co-authoring with an artist in peer-reviewed science publications. 


\section{artnodes}

http://artnodes.uoc.edu

The Artist in the Laboratory: Co-operating (T)reasonably

This problem is common to sciart collaborations. As others have noted, "[t]here was a sobering moment when [scientist] $Y$ was told 'don't put your sciart activities on your science CV, other scientists won't like it" (Glinkowski et al., 2009). Initially, we did not co-author any scholarly articles, but as our trust deepened and our confidence in the significance of our collaborative work grew, we decided to take that risk.

Such skepticism is not restricted to the sciences. Given the importance placed by gallerists and curators on 'branding' artists, problems can arise in exhibition context if an artist wants to name a scientist as an 'equal' partner in the production of an artwork (here I include computer scientists and programmers that do not identify themselves as artists but who work with artists). Describing an artwork as being made by an artist and a scientist challenges the idea of the artist as a 'sole producer' and weakens the aura of the artefact(s). This was my experience when shortlisted for Imaginaria, a digital art award in the late 1990s. I arrived at the Institute of Contemporary Art (ICA) in London, after installing a gallery installation version of the net.art work, TechnoSphere, made with Gordon Selley, a computer scientist, and was asked by the curator to remove Selley's name from the plaque accompanying the work. The infiltration of new media art into the space of the ICA was presented to me as conditional on a denial of equal collaboration with a scientist. I refused and after some argument the plaque remained, but it was an unpleasant experience. One hopes that in the intervening decade such prejudice from MCA towards NMA and interdisciplinary collaboration has changed, but recently, a biomedical scientist noted, "[i]n one collaboration with an artist, I said that I wanted to have my name recognised on the final artistic product. The artist went back to their agent and he said 'if you put your scientist's name on the work it would devalue the artwork..."' (Glinkowski et al., 2009).

\section{Process-based and socially-engaged collaboration}

MCA is familiar, and more comfortable, with the notion of collaboration where both, or all, partners are artists. Collaborating partners may be seen as equal, but the process itself, and its outcomes, can be problematic. There is a history of antagonism by MCA towards art made by groups such as the Fluxus artists and Situationists, frequently cited as the forebears of collaborative art, as their work is often seen in opposition to, not commensurable with, and deliberately outside the territory of, MCA. This is in part related to the form of the works produced, a problem shared with much participatory art, activist art, live art and site-specific art. These are forms of art experienced by MCA as anti-commercial, hard to fund (and in need of up-front funding for production), difficult to sell, and challenging to exhibit in white cube spaces. Many sciart collaborations are seen as difficult to market for similar reasons - they do not necessarily prioritize the production or consumption of an 'art object'. Both NMA and sciart have been accused of supporting the production of 'bad art'. Indeed, more than a few practitioners have not had formal education in a fine art context and can be said to operate with little awareness of MCA.

However, what is more prevalent are fine-art educated artists working in fields of sciart and NMA who do have a keen awareness of the machinations of MCA and are critiquing it. In doing so, they are either placing themselves outside MCA or finding themselves displaced by MCA due to the funding they use for production, the interdisciplinary partnerships that they are part of, or the form of the artifacts that they create. It is important to acknowledge that there is an 'upside' to being 'outside' MCA (until recent devastating budget cuts, access to funding for individual artists and small organizations working with NMA in UK, for example, has been especially good in comparison to funding for equivalents in painting or sculpture). In looking at the no man's land between MCA and NMA, it is important to acknowledge that positioning oneself 'outside' the mainstream may be deliberate for both reasons of access to such funds and to position a practice as 'different to' MCA.

\section{Artworks in no mans' land}

One problem for MCA is that many artworks made through sciart funding schemes have lost their 'purposelessness' and become purposeful, contaminated by their need to educate or engage the public with science. This 'education' is often shared between sciart and NMA - where many works depend on significant prior knowledge, not only of the NMA field, but via reading accompanying texts and instructions displayed alongside artworks, in order for an audience to fully engage with the works. In many sciart works the 'obvious' transfer of knowledge is essential in order that the funders' 'public engagement with science' remit can be seen to be addressed (see Wellcome Trust website). The display of dense texts is an anathema in MCA, contrary to the rhetoric of most gallery exhibitions. Some art objects made using new media processes or technologies find themselves in no man's land because they are not interactive. These works do not relate strongly enough to NMA's 'normative' forms (of which interactivity is the most dominant) to be shown on the NMA exhibition circuit. Many such artworks lie close to the border of MCA, especially when they are objects or 2D images, and indeed some infiltrate the gallery system, for example, John F. Simon Junior's assemblages of screen-based computational artworks that are integrated into "elaborate [...] wall-hung cabinetry" (Princenthal, 2008).

Half a century ago, faced with a lack of understanding and acceptance from MCA, and wanting to focus on a markedly different set of concerns, what we now call new media art exhibited wherever it could. It thrived, forming its own establishment and developing a 


\section{artnodes}

http://artnodes.uoc.edu

separate discourse and a separate international exhibition circuit from MCA. Many of these venues and festivals, such as Transmediale in Berlin, had been the 'home' of other marginalized art practices: film and video art. Subsequently, video art has gradually infiltrated MCA and is no longer seen as 'outside' contemporary art (though it routinely fetches lower prices at auction). As discussions about the relationship between the cultures of NMA and MCA proliferate, NMA may similarly be incorporated into the body of what we describe as MCA. Simultaneously, NMA venues may broaden their selection criteria to include print-based works, 3D objects, and other noninteractive pieces and expand the NMA debate beyond technologies and their social implications. It is useful to think of the artist as agent provocateur, an outsider, to see both NMA and MCA less as territories to be accepted into and more as ones to be infiltrated. However, I would rather be moving freely across open borders and hope that some sort of rapprochement will make that possible.

\section{Reference}

BOURRIAUD, N. (19 June 2010). "Art Basel Conversations, Contemporary Art and New Media: Towards a Hybrid Discourse". [Accessed: 24 June 2011]. $<$ http://www.artbasel.com/go/id/mhv/>
The Artist in the Laboratory: Co-operating (T)reasonably

D'INVERNO, M. ; PROPHET, J. (2005). "Creative conflict in interdisciplinary collaboration: interpretation, scale and emergence". In: E. EDMONDS and R. GIBSON (eds.). Interaction: Systems, Theory and Practice. New York: ACM.

GLINKOWSKI, P.; BAMFORD, A. (2009). "Insight and Exchange: An evaluation of the Wellcome Trust's Sciart programme". [Accessed: 24 June 2011]. $<$ http://www.wellcome.ac.uk/About-us/Publications/Reports/ Public-engagement/Sciart-evaluation-report/index.htm>

PRINCENTHAL, N (2008, April). "John Simon Jr. at Gering and Lopez". Art in America Magazine. Iss. 4.

PROPHET, J. ; D'INVERNO, M. (2006). "Transdisciplinary Research in CELL”. In: P. FISHWICK (ed.). Aesthetic Computing. Cambridge: MIT Press.

WELLCOME TRUST. See the funding criteria for Wellcome in the UK. The EPSRC in the UK has recently cut its similar programme completely.

$<$ http://www.wellcome.ac.uk/stellent/groups/corporatesite/@ msh_grants/documents/guidance/wtx035073.pdf>

WOLPERT, L. (2002). "Which side are you on?" The Observer. London. [Accessed: 24 June 2011]. <http://www.guardian.co.uk/education/2002/mar/10/arts. highereducation $>$

\section{Recommended Citation}

PROPHET, Jane (2011). "The Artist in the Laboratory: Co-operating (T)reasonably". In: Edward A. SHANKEN (Coord.). "New Media, Art-Science and Contemporary Art: Towards a Hybrid Discourse?" [online node]. Artnodes. No. 11, p. 97-101. UOC [Accessed: dd/mm/yy]. $<$ http://artnodes.uoc.edu/ojs/index.php/artnodes/article/view/artnodes-n11-prophet/artnodes-n11-prophet-eng>

ISSN 1695-5951

This article is - unless indicated otherwise - covered by the Creative Commons Spain Attribution 3.0 licence. You may copy, distribute, transmit and adapt the work, provided you attribute it (authorship, journal name, publisher) in the manner specified by the author(s) or licensor(s). The full text of the licence can be consulted here: http://creativecommons.org/licenses/by/3.0/es/deed.en. 


\section{artnodes}

http://artnodes.uoc.edu

The Artist in the Laboratory: Co-operating (T)reasonably

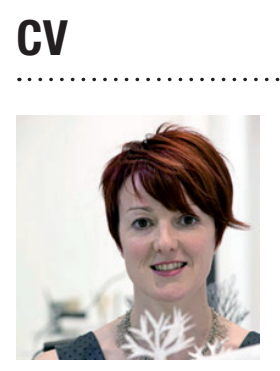

\section{Jane Prophet}

Professor of Art and Interdisciplinary Computing

Goldsmiths College University of London

jane@janeprophet.com

Goldsmiths University of London

New Cross

London SE14 6NW

UK

Jane Prophet graduated in Fine Art in 1987 (Sheffield Hallam University), completing her MA in Electronic Graphics in 1989 (Coventry University) and a PhD in Arts Education in 1995 (Warwick University).

Recent works include The Withdrawing Room, a series of laser cut dictionaries for Samuel Johnson's House (2009); (Trans)Plant (2008), a kinetic aluminium sculpture based on the structure of a plant; Counterbalance(2007), a light based installation commissioned for a flood plain in Australia and Souvenir of England (2007), a preserved apple tree covered in black velvet flocking and displayed in a giant snow dome.

Some of her art pieces are site specific or temporary resulting in no saleable art object. However, she also produces art works using materials that enable her to make Limited Editions of some pieces. Site-specific projects include Conductor, the inaugural installation at The Wapping Project (74 tonnes of water and 120 electro luminescent cables), Decoy, and The Landscape Room, which combine photographs with computer simulated landscapes.

Her work includes large-scale installations, digital prints and objects. Her art reflects her interest in science, technology and landscape. Among her past projects is the award-winning website, TechnoSphere, inspired by complexity theory, landscape and artificial life. Prophet works across disciplines on a number of internationally acclaimed projects that have broken new ground in art, technology and science.

For 2005 and 2006 she was a NESTA Dream Time Fellow, spending a year developing her interdisciplinary collaborations.

In August 2007 she became Professor at Goldsmiths College, specialising in interdisciplinary research in the Computing Department $(<\mathrm{http}: / /$ www. goldsmiths.ac.uk/computing/research.php $>$ ).

Long term projects in development include Net Work, a large floating installation (comprising hundreds of illuminated buoys) and Big Plastic Tree (an artwork built by robots).

Jane works in London and the US east coast, where she has recently relocated her studio.

For more information about the author, visit: <http://www.janeprophet.com>.

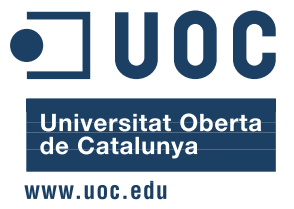

